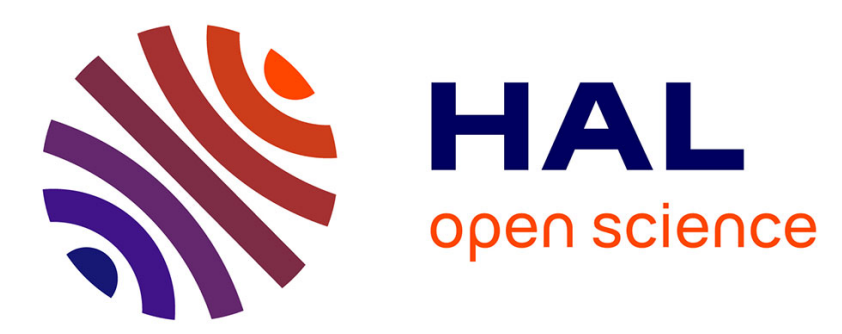

\title{
Comparison of rheological properties of acid gels made from heated casein combined with $\beta$-lactoglobulin or egg ovalbumin
}

Marie-Hélène Famelart, Jérome Tomazewski, Michel Piot, Stéphane Pezennec

\section{- To cite this version:}

Marie-Hélène Famelart, Jérome Tomazewski, Michel Piot, Stéphane Pezennec. Comparison of rheological properties of acid gels made from heated casein combined with $\beta$-lactoglobulin or egg ovalbumin. International Dairy Journal, 2003, 13 (2-3), pp.123-134. 10.1016/S0958-6946(02)00176-0 . hal-02263103

\section{HAL Id: hal-02263103 \\ https://hal.science/hal-02263103}

Submitted on 2 Aug 2019

HAL is a multi-disciplinary open access archive for the deposit and dissemination of scientific research documents, whether they are published or not. The documents may come from teaching and research institutions in France or abroad, or from public or private research centers.
L'archive ouverte pluridisciplinaire HAL, est destinée au dépôt et à la diffusion de documents scientifiques de niveau recherche, publiés ou non, émanant des établissements d'enseignement et de recherche français ou étrangers, des laboratoires publics ou privés. 


\title{
Comparison of rheological properties of acid gels made from heated casein combined with $\beta$-lactoglobulin or egg ovalbumin
}

\author{
Marie-Hélène Famelart*, Jérome Tomazewski, Michel Piot, Stéphane Pezennec \\ Laboratoire de Recherches de Technologie Laitière, Institut National de la Recherche Agronomique, 65, rue de St Brieuc, 35042 Rennes Cedex, France
}

Received 21 June 2002; accepted 18 November 2002

\begin{abstract}
Gelation of heat-treated milk protein solutions by acid fermentation was performed using a model system of micellar casein alone (systR), micellar casein and $\beta$-lactoglobulin (systB) or micellar casein and egg ovalbumin (systO) dissolved in a milk ultrafiltrate and heat-treated at $90^{\circ} \mathrm{C}$ for $24 \mathrm{~min}$. Solubility of globular proteins at given $\mathrm{pH}$ values and their interactions with casein were determined. Particle size and $\zeta$-potential of the protein systems were measured before and after heat treatment. Acid gelation of the heated systems was monitored using dynamic low-amplitude strain oscillation. Ovalbumin alone or with casein produced larger particles than casein alone or with $\beta$-lactoglobulin upon heat treatment. The systems gelled at different $\mathrm{pH}$ values, i.e. $4.88,5.47$ and 5.88 in systR, systB and systO, respectively. The latter two $\mathrm{pH}$ values were clearly related to the $\mathrm{pH}$ of the loss of solubility of the heated globular proteins. While the gelation pattern for systR resembled unheated milk, the pattern for systB and systO showed the usual maximum for $\tan \delta$ of heated milk.
\end{abstract}

(C) 2003 Elsevier Science Ltd. All rights reserved.

Keywords: Ovalbumin; $\beta$-lactoglobulin; Yoghurt; Heat-treatment; Acid gel; Rheology

\section{Introduction}

Heat treatment of milk in the yoghurt process has a marked influence on the microstructure of the protein network and on the rheological and textural properties of the set yoghurt. Compared with unheated milk, the gel from heated milk is formed at a higher $\mathrm{pH}$ value and the decrease in $\tan \delta$ at the time of gel formation is followed by a maximum and a final decrease (Lucey \& Singh, 1998; Lucey, Tamehana, Singh, \& Munro, 1998b). The most significant change is the large increase in modulus or firmness of the yoghurt made from heated milk. Heat treatment of milk reduces the amount of whey expelled from yoghurt measured by drainage (Dannenberg \& Kessler, 1988) or centrifugation (Harwalkar \& Kalab, 1983; Harwalkar \& Kalab, 1986), but the amount increases if quantified by a static method in volumetric flasks (Lucey, Munro, \& Singh, 1998a).

According to Lucey, Tamehana, Singh, and Munro (1998c), the early increase in modulus and the decrease

*Corresponding author. Tel.: + 33-2-99-28-53-43; fax: + 33-2-23-4853-50.

E-mail address: famelart@rennes.inra.fr (M.-H. Famelart). in $\tan \delta$ before its maximum is more probably due to whey protein interactions, while the increase in modulus after the maximum involves casein interactions.

Heat treatment of milk has been the subject of many investigations since 1980 (Smits \& van Brouwershaven, 1980; Singh \& Fox, 1985; Singh \& Fox, 1987; Dalgleish, 1990; Law, 1996; Singh, Robert, Munro, \& Cheng Tet Teo, 1996; Dalgleish, van Mourik, \& Corredig, 1997; Anema \& Klostermeyer, 1997; Anema, 1998; Corredig \& Dalgleish, 1999; Anema \& Li, 2000). Research has been focused on the $\mathrm{pH}$-dependent heat-induced dissociation of casein from micelles and it appears that this dissociation in milk is maximal at $\mathrm{pH}>6.7$ at $60^{\circ} \mathrm{C}$ for $\alpha_{\mathrm{s}^{-}}$and $\beta$-casein, and at $90^{\circ} \mathrm{C}$ for $\kappa$-casein. At temperatures $>60^{\circ} \mathrm{C}$, the dissociation of $\kappa$-casein decreases and that of $\alpha_{\mathrm{s}}$ - and $\beta$-casein increases when milk is devoid of whey proteins. Addition of $\beta$ lactoglobulin $(\beta \mathrm{LG})$ to milk increases the dissociation of $\kappa$-casein, while it decreases that of $\alpha_{\mathrm{s}}$ - and $\beta$-caseins. At $\mathrm{pH}$ values $>6.7, \beta \mathrm{LG}$ interacts with $\kappa$-casein in the soluble phase, while at lower $\mathrm{pH}$ values it interacts with casein micelles (Anema et al., 2000). Addition of $\mathrm{N}$ ethylmaleimide (NEM) to milk before heat treatment causes an increase in the dissociation of $\alpha_{\mathrm{s}^{-}}$and 
$\beta$-caseins and a decrease in $\kappa$-casein dissociation. According to Dalgleish et al. (1997), whey proteins found in the pellet of heated milk are bound to the casein micelles. $\beta$-Lactoglobulin is essential for the binding of $\alpha$-lactalbumin to the micelles. The amount of bound $\alpha$-lactalbumin is related to its concentration in milk, but the addition of $\beta \mathrm{LG}$ in milk does not change the level of incorporation of $\alpha$-lactalbumin into the micellar fraction. These two whey proteins probably interact together in the serum phase before interacting with casein particles.

Whole egg or egg white powder can be added to milk for yoghurt manufacture (Mackenzie, 1982; Muller, Volley, \& Zumstein, 1987). Egg white $\left(470 \mathrm{~g} \mathrm{~kg}^{-1}\right)$ with added sucrose and glucose, soymilk, xanthan gum and skim milk can be fermented with a yoghurt starter (Lin \& Cunningham, 1984). Addition of dried egg white to milk has been found to enhance the production of lactic acid and the growth of lactic acid bacteria, and to increase yoghurt viscosity (Tae, 1995; Tae \& Min, 1995).

An interaction between ovalbumin and $\kappa$-casein has been reported without any heat treatment, although the two proteins are negatively charged (Marshall \& Green, 1980). Heat-induced interactions have been found between ovalbumin and $\kappa$-casein, while no interaction was reported with the other caseins (Sato, Iwatsuki, \& Hayakawa, 1976). There is little agreement about the types of interaction formed during heat treatment of ovalbumin, alone or with other proteins. Discrepancies between studies may be due to differences in sources of proteins and in the methodology used. Some investigators have reported the potential role of disulphide bonds in ovalbumin or egg white in gel formation (Hayakawa \& Nakai, 1985; Margoshes, 1990; Mine, 1992) and in aggregate formation from ovalbumin and $\alpha$-lactabumin (Sun Yuanxia \& Hayakawa, 2001). Gels of whey proteins or egg white are obtained in three stages: aggregation of proteins by hydrophobic interactions, sulphydryl-disulphide interchange and sulphydryl oxidation within the aggregates and perhaps between the aggregates, and multiple hydrogen bonding that occurs on cooling (Beveridge, Jones, \& Tung, 1984). Sulphydryl groups do not seem to take part in the heat-induced interactions between ovalbumin and $\kappa$-casein (Sato et al., 1976). Similarly, disulphide bridging is apparently not involved in heat-induced aggregation of ovalbumin (Doi \& Kitabatake, 1997) or is less important than in gels from gelatin, agar or soybean (Hatta, Kitabatake, \& Doi, 1986). Hydrophobic interactions and hydrogen bonds are probably required, whether with ovalbumin/ casein gels or with ovalbumin gels, but the exact role of these interactions has not been fully established.

Our aim was to demonstrate that when casein particles interact with a whey protein $(\beta \mathrm{LG}$ for instance), the casein particles behave as their covering layer. Hence, particle solubility should decrease when the $\mathrm{pH}$ is close to the isoelectric $\mathrm{pH}\left(\mathrm{pH}_{\mathrm{i}}\right)$ of the whey protein layer. This was established by replacing the whey protein $(\beta \mathrm{LG})$ by another globular protein with different physicochemical properties. Egg ovalbumin was chosen, firstly because it possesses four free thiol groups so it is theoretically capable of interacting with casein through disulphide bonds, and secondly because its $\mathrm{pH}_{\mathrm{i}}$ is 4.75 (Kitabatake, Ishida, \& Doi, 1988), and its molecular mass is $45 \mathrm{kDa}$ (Croguennec, Nau, Pezennec, $\&$ Brulé, 2000). The $\mathrm{pH}_{\mathrm{i}}$ and molecular mass of $\beta \mathrm{LG}$ are 5.1 (Verheul, 1998) and $18 \mathrm{kDa}$, respectively (Hoffmann, 1997).

\section{Materials and methods}

\subsection{System preparation}

\subsubsection{Casein}

A suspension of casein micelles was prepared by microfiltration on a $0.1 \mu \mathrm{m}$ membrane (Exekia, Bazet, France) at $50^{\circ} \mathrm{C}$ to a volume concentration factor (VCF) of 3 and diafiltered 4 times with de-ionized water. The casein retentate was freeze-dried.

\subsection{2. $\beta$-lactoglobulin}

$\beta$-Lactoglobulin was supplied by J. Fauquant (Laboratoire de Recherches de Technologie Laitière INRA, Rennes, France). It was prepared from a whey protein concentrate by precipitation of $\alpha$-lactalbumin by the addition of $3 \mathrm{~mol} \mathrm{~L}^{-1}$ citric acid to $\mathrm{pH} 3.8$, heat treatment at $56^{\circ} \mathrm{C}$ for $30 \mathrm{~min}$, microfiltration of the soluble part on a $0.1 \mu \mathrm{m}$ membrane and diafiltration with 10 volumes of water at $\mathrm{pH} 3.8$. The filtrate and the diafiltrate containing $\beta$ LG were concentrated on a DDS plane membrane (GEA, Soeborg, Denmark; molecular mass cut-off, $10 \mathrm{kDa}$ ) and freeze dried.

\subsubsection{Ovalbumin}

Egg albumen was separated from commercial eggs and diluted (1 in 3) with MilliQ water. The $\mathrm{pH}$ was adjusted to 6 with $1 \mathrm{~mol} \mathrm{~L}^{-1} \mathrm{HCl}$ and stored overnight at $4{ }^{\circ} \mathrm{C}$. Following centrifugation at $2000 \mathrm{~g}$ for $3 \mathrm{~min}$ at $20^{\circ} \mathrm{C}$, the supernatant was adjusted to $\mathrm{pH} 8$ with $1 \mathrm{~mol} \mathrm{~L}^{-1} \mathrm{NaOH}$, and centrifuged at $25,000 \mathrm{~g}$ for 20 min just before injection on the separation column to exclude aggregates. Preparative chromatography was performed on a Q Sepharose Fast Flow column (Pezennec et al., 2000). The eluate fraction of ovalbumin was concentrated and diafiltered on an Omega $10 \mathrm{kDa}$ membrane (Filtron, Coignières, France) and freezedried.

\subsubsection{Milk ultrafiltrate}

Milk ultrafiltrate (UF) was prepared from fresh pasteurised milk on an $8 \mathrm{kDa}$ TAMI membrane (Tami 
Industries, Nyons, France) and stored at $4^{\circ} \mathrm{C}$ after sterilisation on a $0.2 \mu \mathrm{m}$ sterile Nalgene membrane.

\subsubsection{Suspension}

Casein at $35 \mathrm{~g} \mathrm{~kg}^{-1}$, alone or with either $\beta \mathrm{LG}$ or ovalbumin at $4 \mathrm{~g} \mathrm{~kg}^{-1}$, was dissolved in the milk ultrafiltrate by vigorous agitation followed by gentle agitation for $1 \mathrm{~h}$. Twenty-seven grams of the resulting suspension was introduced into a glass tube containing $12.5 \mathrm{mg}$ of yeast extract (Bio Springer, Maisons-Alfort, France). Three tubes were prepared and heat-treated together. Heat treatment was performed at $90^{\circ} \mathrm{C}$ for $24 \mathrm{~min}$, taking $14 \mathrm{~min}$ to reach $90^{\circ} \mathrm{C}$. The systems are referred to as systR (with casein alone), systB (with casein and $\beta \mathrm{LG}$ ) or systO (with casein and ovalbumin).

Systems without casein were also prepared in UF at the same globular protein concentration and heat treated the same way as suspensions, and are referred to as systUFR (with UF alone), systUFB (UF with $\beta$ LG) and systUFO (UF with ovalbumin).

\subsection{Analysis}

\subsubsection{Soluble casein}

The sedimentation of proteins in the different systems was performed by centrifugation of a $5 \mathrm{~mL}$ sample at $50,000 \mathrm{~g}$ for $90 \mathrm{~min}$ at room temperature. The separation was performed on an L8-55 ultracentrifuge with a Sw55.Ti rotor (Beckman Instruments France S.A., Gagny, France). Supernatants and pellets were frozen and stored before analysis by sodium dodecyl sulphate polyacrylamide gel electrophoresis (SDS-PAGE) and high pressure liquid chromatography (HPLC).

\subsubsection{SDS-page}

Each pellet was resuspended in $10 \mathrm{~g} \mathrm{Na}_{2}$ EDTA-Na EDTA $\left(25 \mathrm{~g} \mathrm{~L}^{-1}, \mathrm{pH} 6.8\right)$. Water $(10 \mathrm{~g})$ was added to the suspension and the suspension was stirred at $4{ }^{\circ} \mathrm{C}$ overnight. A portion of the resulting resuspended pellet ( $4 \mathrm{~g})$ was precipitated at $\mathrm{pH} 4.6$ with $1 \mathrm{~mol} \mathrm{~L}^{-1} \mathrm{HCl}$ $(\sim 130 \mu \mathrm{L})$ at room temperature and centrifuged $(1000 \mathrm{~g}$, $15 \mathrm{~min}, 20^{\circ} \mathrm{C}$ ). Pellets were washed with water at $\mathrm{pH} 4.6$, then centrifuged $\left(1000 \mathrm{~g}, 15 \mathrm{~min}, 20^{\circ} \mathrm{C}\right)$ and finally resuspended in $10 \mathrm{mmol} \mathrm{L}^{-1}$ Tris- $10 \mathrm{mmol} \mathrm{L}^{-1} \mathrm{Na}_{2}$ EDTA, $25 \mathrm{~g} \mathrm{~L}^{-1}$ SDS at $\mathrm{pH} 8.2$ and frozen. This fraction, called the micellar acid-precipitable fraction, should contain micellar casein, as well as denatured globular proteins either as large polymers or associated with micellar casein.

Supernatants $(0.5 \mathrm{~mL})$ were precipitated at $\mathrm{pH} 4.6$, washed with water at $\mathrm{pH} 4.6$, resuspended and frozen as for pellets. This fraction, called the soluble acidprecipitable fraction, should contain the soluble caseins or the soluble casein-whey protein complexes and denatured whey proteins in small aggregates.
Samples of the micellar fraction $(10 \mu \mathrm{L})$ and soluble fraction $(20 \mu \mathrm{L})$ with and without reduction at $37^{\circ} \mathrm{C}$ for $1 \mathrm{~h}$ with 2 -mercaptoethanol $\left(0.71 \mathrm{~mol} \mathrm{~L}^{-1}\right.$ final concentration), were examined by SDS-PAGE $\left(150 \mathrm{~g} \mathrm{~L}^{-1}\right)$ using the MiniProtean II system (Biorad, Ivry sur Seine, France). Staining was performed with Coomassie Blue and slots were scanned with Bioimage Software (Millipore, Saint Quentin-en-Yvelynes, France). A prestained low range SDS-PAGE standard (Biorad, ref 161-0305; molar weight from 14 to $94 \mathrm{kDa}$ ) was also loaded.

\subsubsection{Reverse phase HPLC}

Serum casein in the supernatant (prepared at $50000 \mathrm{~g}$ ) was estimated by reverse phase HPLC (RP-HPLC) on a $\mathrm{C}_{4}$ Vidac 214 TP 54 column (Interchim, Montluçon, France) at $40^{\circ} \mathrm{C}$. Solvent A consisted of $1.06 \mathrm{~mL} \mathrm{~L}^{-1}$ trifluoroacetic acid (TFA) in water and solvent $\mathrm{B}$ of $1 \mathrm{~mL} \mathrm{~L}^{-1}$ TFA in $80 \%$ acetonitrile in water. A linear gradient at $1 \mathrm{~mL} \mathrm{~min}^{-1}$ from $37 \%$ to $54 \%$ B was performed in $30 \mathrm{~min}$ and $100 \% \mathrm{~B}$ was applied over $32 \mathrm{~min}$. Proteins were detected at $280 \mathrm{~nm}$. Supernatants were diluted 3 to 4 in a solvent composed of $8 \mathrm{~mol} \mathrm{~L}^{-1}$ urea, $1 \mathrm{~mol} \mathrm{~L}^{-1}$ TRIS, $13 \mathrm{~g} \mathrm{~L}^{-1}$ sodium citrate at $\mathrm{pH} 7$, then 9 to 10 in an aqueous solution of $30 \mathrm{~g} \mathrm{~L}^{-1}$ dithiothreitol and then 1-10 in solvent $\mathrm{A}$. The fraction $(\%)$ of soluble casein was determined by calculating the ratio of the peak area of the corresponding casein in the supernatant to the area of the same peak in the unheated suspension. Two injections were performed.

\subsubsection{Ion exchange $H P L C$}

Due to partially reversible adsorption of ovalbumin to the column used in RP-HPLC, an anion exchange method (Croguennec et al., 2000) was preferred for quantification of the residual native globular proteins. Elution over $45 \mathrm{~min}$ was performed on a $\mathrm{Q} / \mathrm{S}$ HyperD $10 / 20$ Biosepra column with a $\mathrm{NaCl}$ gradient from 0 to $0.5 \mathrm{~mol} \mathrm{~L}^{-1}$ in a Tris buffer $\left(50 \mathrm{mmol} \mathrm{L}^{-1}-\mathrm{pH} 8\right)$ at $1 \mathrm{~mL} \mathrm{~min}{ }^{-1}$. The eluate was spectrophotometrically monitored at $280 \mathrm{~nm}$. Suspensions and supernatants were diluted as in RP-HPLC without reduction. Standard injection of $\beta \mathrm{LG}$ and ovalbumin allowed quantification of residual globular proteins.

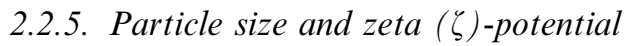

Mean particle size and $\zeta$-potential were estimated by a dynamic light-scattering method with a Malvern Zeta sizer 3000 HS (Malvern France) in a 1000-fold dilution of the protein systems in a buffer containing $20 \mathrm{mmol}$ imidazole, $50 \mathrm{mmol} \mathrm{NaCl}$ and $5 \mathrm{mmol}$ calcium chloride per litre at pH 7 (Dalgleish, 1984). Measurements were performed at $25^{\circ} \mathrm{C}$ using the method of Michalski, Michel, and Briard (2002). One measurement for particle size and the mean of 5 measurements for $\zeta$ potential were obtained. Four to 6 suspensions in each system were characterised. 
Mean particle size analysis was also performed on the unheated and heated suspensions of systUFR, systUFB and systUFO.

\subsubsection{Viscosity}

The viscosity of the protein systems was measured in a viscometer (Low-shear 30 sinus, Contraves, Lamy, Caluire, France) between 1.5 and $40 \mathrm{~s}^{-1}$ at $20^{\circ} \mathrm{C}$.

\subsubsection{8-anilino-1-naphthalenesulphonic acid (ANS) titration}

The protein systems were diluted 200 -fold with milk UF and titrated with an aqueous solution of $1.5 \mathrm{mmol} \mathrm{L}^{-1}$ ANS. Fluorescence emission intensity was measured at $480 \mathrm{~nm}$ for an excitation wavelength of $390 \mathrm{~nm}$, with the emission and excitation slits set at $2.5 \mathrm{~nm}$ bandwidth. The maximum ANS concentration was chosen to reach the maximum intensity. A diluted suspension without ANS was used as a blank. The maximum intensity (minus the blank value) and the apparent dissociation constant of the complex between proteins and ANS, calculated as the concentration of ANS required to obtain half the maximum intensity, were calculated.

\subsubsection{Gelation}

The heated systems were equilibrated at $42^{\circ} \mathrm{C}$ for $15 \mathrm{~min}$ and were inoculated with lyophilised non-ropy cultures of $S$. thermophilus ST060 at $2 \times 10^{6}$ colony forming units $\mathrm{mL}^{-1}$ (CFU) and L. bulgaricus LB340 at $2 \times 10^{5} \mathrm{CFU} \mathrm{mL}^{-1}$ (Texel, Rhodia Food, Dangé Saint Romain, France).

The kinetics of acidification were monitored using a thin $\mathrm{pH}$ electrode (Inlab 423, Mettler Toledo, Paris, France) immersed in the rheometer cup.

The elastic $\left(G^{\prime}\right)$ and viscous $\left(G^{\prime \prime}\right)$ moduli and the loss tangent, $\tan \delta$ were monitored at $42^{\circ} \mathrm{C}$ as a function of time in an AR1000 rheometer (TA instruments, Waters, St Quentin en Yvelines, France), in oscillatory mode with coaxial cylinder geometry at a frequency of $1 \mathrm{~Hz}$ and a strain of 0.02 . The suspension was placed in the cup and covered with a thin layer of paraffin to prevent dehydration during incubation. Measurements were recorded dynamically at $3.36 \mathrm{~min}$ intervals. The gel time was defined as the point where $G^{\prime}>1 \mathrm{~Pa}$. Gelation was monitored on two or more occasions for each protein system.

\subsubsection{Scanning electron microscopy of acid gels}

Acid gels were formed as described above. At $\mathrm{pH}$ 4.6, the gels were placed at $4{ }^{\circ} \mathrm{C}$ and stored overnight. Gels were observed by scanning electron microscopy under a Philips XL20 (Bobigny, France) microscope. Samples were fixed in glutaraldehyde $\left(25 \mathrm{~mL} \mathrm{~L}^{-1}\right)$ in $0.1 \mathrm{~mol} \mathrm{~L}^{-1}$ sodium cacodylate buffer, pH 7.2 for $5 \mathrm{~d}$ at $4^{\circ} \mathrm{C}$. After rinsing with cacodylate and water, pieces were dehy- drated in alcohol series and critical point dried. Fractured samples were glued to the sample holder, gold coated and observed at $10 \mathrm{kV}$. For each gel, 3 or 4 photographs were taken at magnifications of 20,000 or $10,000 \times$. An average of 67 particles were measured per photograph and their diameters determined for each gel. The median particle size, was measured as the DL 50 (in $\mathrm{nm}$ ): half of the particles were smaller in size than the DL 50, while the other half were larger.

\subsubsection{Globular protein solubility}

Samples of $\beta \mathrm{LG}$ or ovalbumin were initially dissolved in UF at $4 \mathrm{~g} \mathrm{~kg}^{-1}$, heat-treated as in 2.1.5 and further diluted ( 1 in 5) in milk ultrafiltrates adjusted from $\mathrm{pH}$ 6.5 to 1.6 by the addition of concentrated $\mathrm{HCl}$. The $\mathrm{pH}$ values and turbidity (absorbance at $600 \mathrm{~nm}$ ) of the diluted samples were measured against water. The diluted samples were centrifuged at $3000 \mathrm{~g}$ for $15 \mathrm{~min}$ at $20^{\circ} \mathrm{C}$ and the supernatants diluted 20 -fold in a $20 \mathrm{mmol} \mathrm{L}^{-1}$ Tris $\mathrm{HCl}, 4 \mathrm{~mol} \mathrm{~L}^{-1}$ urea buffer, $\mathrm{pH} 8$. The absorbance of the diluted supernatant was measured at $280 \mathrm{~nm}$ against the urea buffer.

\subsubsection{Statistical analysis}

A Student's $t$-test was used to determine if the averages of two sets of measurements were significantly different at $P<0.05$.

\section{Results}

\subsection{Particle size, $\zeta$ potential and $\mathrm{pH}$ of the protein systems}

The heated and unheated syst $\mathrm{R}$ and syst $\mathrm{B}$ suspensions and the unheated systO suspension had the same particle size at $\mathrm{pH}$ 7. Heat treatment led to a substantial increase in particle size for systO. The standard deviation of the particle size of systO was also higher than for the other two systems (Table 1).

It was not possible to detect any particles in systUFR. However, particles at 200 and $590 \mathrm{~nm}$ were detected in systUFB and systUFO before heat treatment. These particles may have been undissolved matter. Heat treatment of systUFO led to high particle sizes. While systUFR, systUFB and systUFO were translucent before heat treatment, the heat treatment resulted in a hazy appearance in systUFR and systUFB and a precipitate at the bottom of the tube in systUFO. This precipitate was easily maintained in suspension after agitation.

The $\zeta$ potential of the 3 protein systems (systR, systB and systO) was identical and was not affected by heat treatment (Table 1).

The initial $\mathrm{pH}$ value of the 3 systems was 6.66 . 
Table 1

Particle size and zêta-potential ( $\zeta$ potential) of milk ultrafiltrate (systUFR) and different protein systems dispersed in milk ultrafiltrate: $\beta$ lactoglobulin (systUFB), ovalbumin (systUFO), micellar casein (systR), micellar casein plus $\beta$-lactoglobulin (systB) and micellar casein plus ovalbumin (systO). Each of the above were either unheated (NHT) or heat treated (HT) at $90^{\circ} \mathrm{C}$ for $24 \mathrm{~min}$

\begin{tabular}{|c|c|c|c|c|c|c|}
\hline & \multicolumn{6}{|c|}{ Particle size and $\zeta$ potential $^{\mathrm{a}}$} \\
\hline & \multicolumn{2}{|c|}{ SystUFR } & \multicolumn{2}{|l|}{ SystUFB } & \multicolumn{2}{|c|}{ SystUFO } \\
\hline & NHT & HT & NHT & HT & NHT & HT \\
\hline \multirow[t]{3}{*}{ Particle size (nm) } & - & 783 & 200 & 262 & 590 & 3436 \\
\hline & SystR & & SystB & & SystO & \\
\hline & NHT & HT & NHT & HT & NHT & HT \\
\hline Particle size $(\mathrm{nm})$ & $232.7 b$ & $201.8 b$ & $237.5 b$ & $202.9 b$ & $236.9 b$ & $530.6 \mathrm{c}$ \\
\hline Standard deviation ( $\mathrm{nm}$ ) & 17.2 & 3.8 & 6.3 & 3.2 & 21.2 & 95.6 \\
\hline$\zeta$ potential $(\mathrm{mV})$ & $-19.1 b$ & $-19.3 b$ & $-19.35 b$ & $-18.42 b$ & $-18.8 b$ & $-19.1 \mathrm{~b}$ \\
\hline Standard deviation $(m V)$ & 0.3 & 2.1 & 1.4 & 2.1 & 0.7 & 0.9 \\
\hline
\end{tabular}

${ }^{\mathrm{a}}$ Presented values for systR, systB and systO are the means of 5 to 6 replicate treatments.

Values within a row not sharing the same letters differ significantly $(P<0.05)$.

\subsection{Viscosity}

The Newtonian viscosity of both unheated systR and systB and unheated systO was between 2 and $3 \mathrm{mPas}$. Heat-treated systO was thixotropic and underwent shear-thinning; the viscosity decreased from $30 \mathrm{mPa}$ at $1.7 \mathrm{~s}^{-1}$ to $11 \mathrm{mPas}$ at $37 \mathrm{~s}^{-1}$.

\subsection{Effects of heat treatment on soluble casein and globular proteins}

In syst $B$, heat treatment led to a considerable increase in the level of soluble $\kappa$-casein and to a decrease in the level of soluble $\alpha_{\mathrm{s} 1}$-casein (Table 2). In the other systems, the soluble phases of heated and unheated systems were the same.

Acid-precipitable bands from micellar and soluble fractions of heated and unheated systems, with and without reduction with 2-mercaptoethanol, were compared by SDS-PAGE (Fig. 1; results in the absence of reducing agent are not shown). Heating systB and systO led to the appearance of a light band of $\beta \mathrm{LG}$ or ovalbumin in the micellar fractions and to larger bands of these proteins in the soluble fractions (Table 3). The relative intensity of the $\beta \mathrm{LG}$ band in the soluble fraction from heated systB was very high. In contrast, the intensity of the ovalbumin band in the soluble fraction of systO scarcely increased on heating. Heat treatment of systB led to an increase in soluble $\kappa$-casein and to a decrease in soluble $\alpha_{\mathrm{s}}$-caseins. In the heated systO, no change was evident in the distribution of casein with heat treatment. When SDS-PAGE was performed without reduction of samples, neither $\beta$ LG nor ovalbumin appeared in any slot of acid-precipitable fractions of systB and systO.

$\beta$-Lactoglobulin and ovalbumin, both in suspension and in supernatant, as quantified by anion exchange
HPLC in non-reducing conditions, were absent in systB and systO when heat-treated. This indicates that there was no more native globular protein in heated systO and systB.

\subsection{Surface hydrophobicity}

Maximum fluorescence intensity of systB and systO was increased with heat treatment, but not in systR (Table 4). Heat treatment did not significantly change the apparent dissociation constant of the complex between ANS and hydrophobic residues of proteins.

\subsection{Globular protein solubility}

$\beta$-Lactoglobulin and ovalbumin dissolved in milk ultrafiltrate and heat-treated lost their solubility at $\sim \mathrm{pH}$ 5.5 and 6.0 , as measured by turbidity or by absorbance of the soluble fraction (Fig. 2). The $\mathrm{pH}$ range of insolubilisation appeared much greater for ovalbumin than for $\beta$ LG. However, the turbidity of ovalbumin at $\mathrm{pH} 6.6$ was greater than the turbidity of $\beta \mathrm{LG}$. The absorbance of the supernatant in the $\mathrm{pH}$ range where the solubility was reduced was high, due to the absorbance of milk ultrafiltrate itself.

\subsection{Acid gelation}

The kinetics of acidification were similar for all three systems. The lag phase (time for the initial $\mathrm{pH}$ to decrease by 0.01 ) lasted $\sim 1 \mathrm{~h}$ and it took $\sim 5 \mathrm{~h}$ to reach $\mathrm{pH}$ 4.6.

The changes in $G^{\prime}$ and $\tan \delta$ with $\mathrm{pH}$ are presented in Fig. 3. The results indicated wide variability for $G^{\prime}$ for each protein system, probably due to the numerous stages of system preparation and to the rheological measurements, but the decrease in $\tan \delta$ was fairly 
Table 2

Percentage of each casein in the soluble phase of protein systems: micellar casein (systR), micellar casein plus $\beta$-lactoglobulin (systB) and micellar casein plus ovalbumin (systO). Each of the above were either unheated (NHT) or heat treated (HT) at $90^{\circ} \mathrm{C}$ for $24 \mathrm{~min}$

\begin{tabular}{|c|c|c|c|c|c|c|}
\hline & \multicolumn{6}{|c|}{ Percentage of soluble caseins ${ }^{\mathrm{a}}$} \\
\hline & \multicolumn{2}{|l|}{ SystR } & \multicolumn{2}{|l|}{ SystB } & \multicolumn{2}{|l|}{ SystO } \\
\hline & NHT & HT & NHT & HT & NHT & HT \\
\hline$\kappa$-cas & $12.02 \pm 2.01 \mathrm{~b}$ & $11.68 \pm 0.05 b$ & $14.97 \pm 1.64 b$ & $41.15 \pm 2.15 c$ & $13.00 \pm 0.94 b$ & $10.90 \pm 1.02 b$ \\
\hline$\alpha_{\mathrm{s} 2}$-cas & $6.62 \pm 5.16$ & $4.83 \pm 1.54$ & $4.88 \pm 1.03$ & $1.53 \pm 2.17$ & $4.06 \pm 0.71$ & $7.22 \pm 4.10$ \\
\hline$\alpha_{\mathrm{s} 1}$-cas & $5.28 \pm 1.52$ & $4.79 \pm 0.22$ & $6.76 \pm 0.54$ & $1.85 \pm 0.02$ & $5.18 \pm 0.06$ & $4.44 \pm 0.09$ \\
\hline$\beta$-cas & $8.22 \pm 2.89$ & $8.01 \pm 0.61$ & $12.78 \pm 0.95$ & $10.46 \pm 0.51$ & $8.28 \pm 0.29$ & $7.50 \pm 0.13$ \\
\hline
\end{tabular}

${ }^{\text {a }}$ Presented values are the means of 2 replicate analyses. The values after the \pm sign indicate the standard deviations. Values within a row not sharing the same letters differ significantly $(P<0.05)$, no letter means no statistical difference.

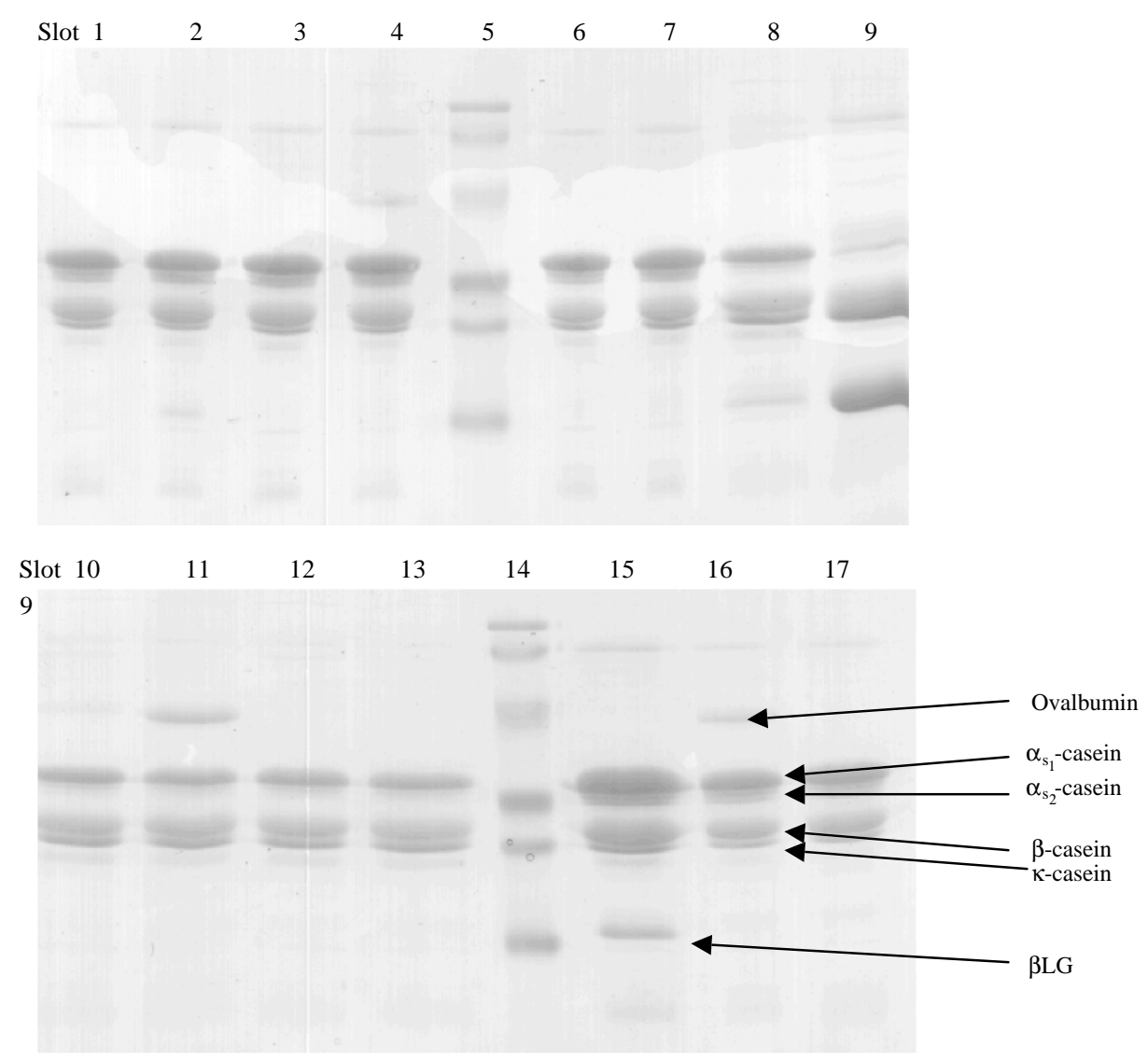

Fig. 1. Sodium dodecyl sulphate polyacrylamide gel electrophoresis (SDS-PAGE) analysis of micellar acid-precipitable protein, soluble acidprecipitable protein and total protein of different protein systems after reduction with 2-mercaptoethanol. The protein systems consisted of proteins suspended in a milk ultrafiltrate: SystR, $35 \mathrm{~g} \mathrm{~kg}^{-1}$ micellar casein; systB, $35 \mathrm{~g} \mathrm{~kg}^{-1}$ micellar casein plus $4 \mathrm{~g} \mathrm{~kg}^{-1} \beta$-lactoglobulin; systO, $35 \mathrm{~g} \mathrm{~kg}^{-1}$ micellar casein plus $4 \mathrm{~g} \mathrm{~kg}^{-1}$ egg ovalbumin. Each of the above were either unheated (NHT) or heat treated (HT) at $90^{\circ} \mathrm{C}$ for $24 \mathrm{~min}$. Micellar and soluble protein fractions were recovered in the pellet and the supernatant, respectively, after centrifugation $\left(50,000 \mathrm{~g}-90 \mathrm{~min}-20^{\circ} \mathrm{C}\right)$. Acidprecipitable fractions were prepared by precipitation at $\mathrm{pH} 4.6$, and washing of the soluble and micellar fractions in water at $\mathrm{pH} 4.6$. Micellar acidprecipitable protein fraction: unheated, slot 1 (systB), 3 (systO) and 6 (systR); heat-treated, slot 2 , 4 and 7 (10 $\mu \mathrm{L}$ each, respectively); soluble acidprecipitable protein fraction, unheated, slot 8 (systB), 10 (systO) and 12 (systR); heat-treated, slot 9, 11 and 13 ( $20 \mu \mathrm{L}$ each, respectively); total protein from unheated systB, systO and systR (slot 15, 16 and 17, respectively); standards from 14 to $94 \mathrm{kDa}$ (slot 5 and $14 ; 5 \mu \mathrm{L}$ ). See text for details of protein systems and fractions, and heat treatment applied.

reproducible. The $\mathrm{pH}$ at gelation was $\sim 4.88 \pm 0.01$, $5.47 \pm 0.08$ and $5.88 \pm 0.03$ for systR, systB and systO, respectively. While $\tan \delta$ decreased constantly in systR, a local maximum of $\tan \delta$ was found at $\mathrm{pH} 4.9$ for systB and at $\mathrm{pH} 5$ for systO. The pattern for systR resembled that reported for unheated milk (Lucey et al., 1998a, b). 
Table 3

Percentage of globular proteins in soluble and micellar acid-precipitable fractions of different protein systems: micellar casein plus $\beta$-lactoglobulin (systB) and micellar casein plus ovalbumin (systO)

\begin{tabular}{lllll}
\hline Percentage of globular proteins in fractions & SystB & & SystO \\
\cline { 2 - 3 }$(\beta$-lactoglobulin in systB; ovalbumin in systO) & NHT & HT & NHT & 0 \\
\hline Micellar acid-precipitable fraction (\%) & 0 & 10 & 3 & 20 \\
Soluble acid-precipitable fraction (\%) & 0 & 97 & 3 & 15 \\
Total acid-precipitable fractions (\%) & 0 & 35
\end{tabular}

Each of the above protein systems was either unheated (NHT) or heat treated (HT) at $90^{\circ} \mathrm{C}$ for 24 min. Partitions were calculated from the integration of bands of sodium dodecyl sulphate polyacrylamide gel electrophoresis (SDS-PAGE) in reducing conditions (see Fig. 1). Percentages were determined by calculating the ratio of the integrated band in the soluble and micellar acid-precipitable fractions to the integrated band in the total fraction of each system.

Table 4

Maximum fluorescence intensity, as determined by titration with 8anilino-1-naphthalenesulfonic acid (ANS), of surface hydrophobicity of different protein systems: micellar casein (systR), micellar casein plus $\beta$-lactoglobulin (systB) and micellar casein plus ovalbumin (systO). Each of the above was either unheated (NHT) or heat treated (HT) at $90^{\circ} \mathrm{C}$ for $24 \mathrm{~min}$

\begin{tabular}{lll}
\hline & \multicolumn{3}{l}{ Maximum fluorescence intensity ${ }^{\mathrm{a}}$ (arbitrary units) } \\
\cline { 2 - 3 } & NHT & HT \\
\hline SystR & $152.03 \pm 18.05 \mathrm{~b}(3)$ & $143.67 \pm 7.51 \mathrm{~b}(3)$ \\
SystB & $151.40 \pm 6.80 \mathrm{~b}(5)$ & $165.28 \pm 9.46 \mathrm{c}(5)$ \\
SystO & $147.80 \pm 6.95 \mathrm{~b}(4)$ & $166.52 \pm 12.64 \mathrm{c}(4)$ \\
\hline
\end{tabular}

${ }^{a}$ Values presented are the means of replicate treatments, the number of which is given in brackets. The values after the \pm sign indicate the standard deviations.

Values within a row not sharing the same letters differ significantly $(P<0.05)$.

The pattern for systB resembled that found for heated milk, which has a local maximum of $\tan \delta$ at $\mathrm{pH} 5.0-5.2$ (Lucey et al., 1998c; Laligant, Famelart, Paquet, \& Brulé, 2003). The $\tan \delta$ values between $\mathrm{pH} 5.0$ and 4.0 were markedly lower for systO than for systB or systR, indicating that systO constituted the most elastic gel system. In systB and systO, $G^{\prime}$ increased from the gel point to $\mathrm{pH} 4$ and a shoulder was observed on the curve at $\sim \mathrm{pH}$ 5. Values of $G^{\prime}$ were very low for systR at acid $\mathrm{pH}$, as in unheated milk, but increased to $200-250 \mathrm{~Pa}$ and $500-600 \mathrm{~Pa}$ with the addition of $\beta \mathrm{LG}$ or ovalbumin, respectively.

\subsection{Scanning electron microscopy}

The microstructures of the acid gels from the different protein systems are shown in Fig. 4. SystR, with casein alone, formed a coarse gel comprised of large particles. The DL 50 of particles in gels with casein alone was found to be between 750 and $850 \mathrm{~nm}$. In contrast, particles in gels containing casein and globular proteins (i.e. systB, systO) were less clustered than those of systR (with branched chains a few particles thick and with much smaller particles). The DL 50 was at $350-500 \mathrm{~nm}$ and $350-400 \mathrm{~nm}$ in systB and systO, respectively. Pores in gels of systB and systO appeared smaller and more uniformly distributed than in gels of systR.

\section{Discussion}

\subsection{Differences in the behaviour of ovalbumin and $\beta L G$}

The particle size in systO was greatly increased by the heat treatment, although the particle size in heated systUFO was higher than that in the heated systO. Casein particles seemed to have a stabilising influence on ovalbumin during the heat treatment. However, the heated suspensions probably contained a mixture of particles of different sizes, so that it is difficult to conclude. No increase in viscosity was observed with heat treatment of systUFO. In fact, the increase in particle size in systO was related to the high viscosity level of this heat-treated suspension and to the loss of Newtonian behaviour. $\beta \mathrm{LG}$ and ovalbumin probably aggregated in different ways. The fact that heat-treated ultrafiltrate alone gave strong turbidity complicates the understanding of complexes formed during heating. Casein, ovalbumin and denatured whey proteins are able to stabilise a calcium phosphate solution into stable colloidal complexes (Visser, 1962; Halbert, O'Kennedy, Hallihan, \& Kelly, 2000). It is noteworthy that the model systems in the current study were composed of $0.27 \mathrm{mmol} \mathrm{L}^{-1} \quad \kappa$-casein and $0.22 \mathrm{mmol} \mathrm{L}^{-1} \beta \mathrm{LG}$ or $0.08 \mathrm{mmol} \mathrm{L}^{-1}$ ovalbumin. Denaturation and polymerisation reactions differ in reaction order with the concentration of substrate and could therefore progress differently depending on the protein system used for acid gelation.

SDS-PAGE showed that $\beta$ LG (and ovalbumin) were present in the acid precipitable pellets of the heated suspensions of systB (and systO) in the presence of 2mercaptoethanol. This can be attributed to the presence of: (i) globular proteins in large polymers that were pelleted with micellar casein and were acid precipitable and (ii) casein-globular protein complexes. Moreover, 


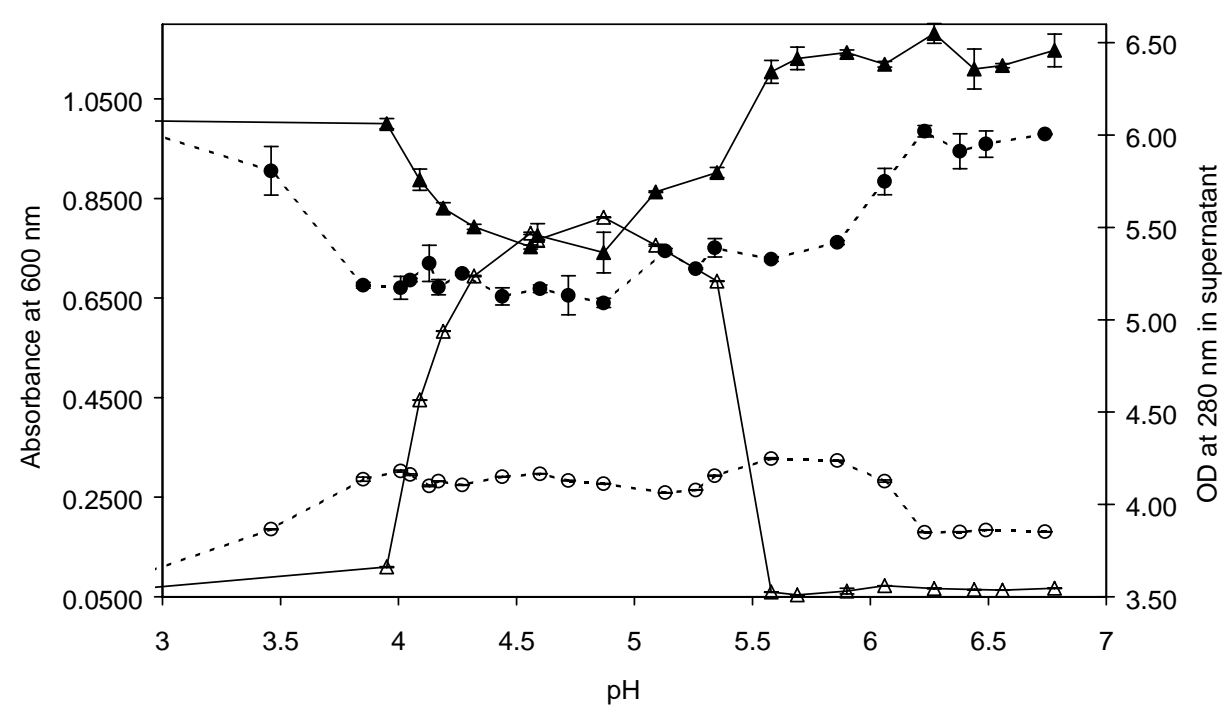

Fig. 2. Effects of $\mathrm{pH}$ on solubility of $\beta$-lactoglobulin and ovalbumin dispersed $\left(4 \mathrm{~g} \mathrm{~kg}^{-1}\right)$ in milk ultrafiltrate, following heat treatment at $90^{\circ} \mathrm{C}$ for $24 \mathrm{~min}$. Turbidity of the heated protein systems (measured by absorbance at $600 \mathrm{~nm}$ ) after dilution $1-5$ in ultrafiltrate which had been previously adjusted to different $\mathrm{pH}$ values in the range 6.5-1.6 ( $\beta$-lactoglobulin: $-\triangle-$; ovalbumin: - - $\bigcirc--)$. Dilute solutions at $\mathrm{pH}$ 6.5-1.6 were centrifuged $\left(3000 \mathrm{~g}-15 \mathrm{~min}-20^{\circ} \mathrm{C}\right)$; the supernatants were diluted 20 -fold in a tris- $\mathrm{HCl}$ buffer containing $4 \mathrm{~mol} \mathrm{~L}^{-1}$ urea at $\mathrm{pH} 8$ and the absorbance was measured at $280 \mathrm{~nm}$ : $\beta$-lactoglobulin: - $\mathbf{\Lambda}$ - ; ovalbumin: - - - -. Error bars represent standard deviations for replicate analyses.

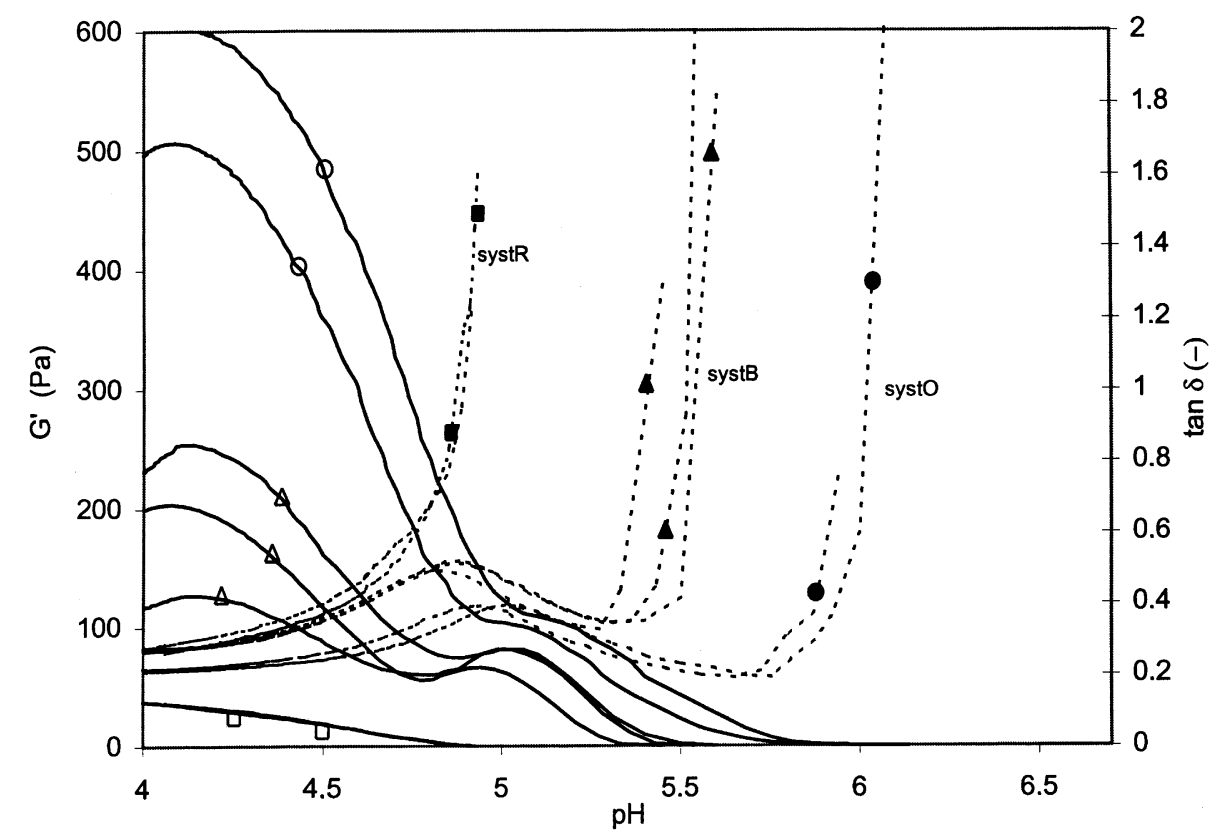

Fig. 3. Elastic shear modulus, $G^{\prime}$ (solid lines, open symbols) and loss tangent, $\tan \delta$ (broken lines, closed symbols) as a function of pH during acid gelation of the different heat-treated protein systems $\left(90^{\circ} \mathrm{C}\right.$ for $24 \mathrm{~min}$ ). Micellar caseins (systR; $\square$, $\left.\mathbf{\square}\right)$, micellar casein plus $\beta$-lactoglobulin (systB; $\boldsymbol{\Delta}, \triangle$ ), and micellar casein plus ovalbumin (systO; $\bigcirc, \mathbf{0}$ ). Slow quiescent acidification was achieved by addition of a starter culture to the systems at $42^{\circ} \mathrm{C}$. See text for details of protein systems and heat treatment. Two or three replicate treatments.

$\beta \mathrm{LG}$, and to a lesser extent ovalbumin, were recovered in the acid precipitable supernatant of heated suspensions of systB and systO in the presence of 2mercaptoethanol. This can be attributed to the presence of: (i) denatured but non-aggregated globular proteins, which were probably acid insoluble, (ii) globular proteins in small polymers, which were "soluble" in the current centrifugation conditions, and (iii) soluble casein-globular protein complexes. The different partition of soluble casein with heat treatment in the presence of $\beta \mathrm{LG}$ suggests that an interaction between soluble $\kappa$ casein and $\beta$ LG was probable. If it occurred, such an 

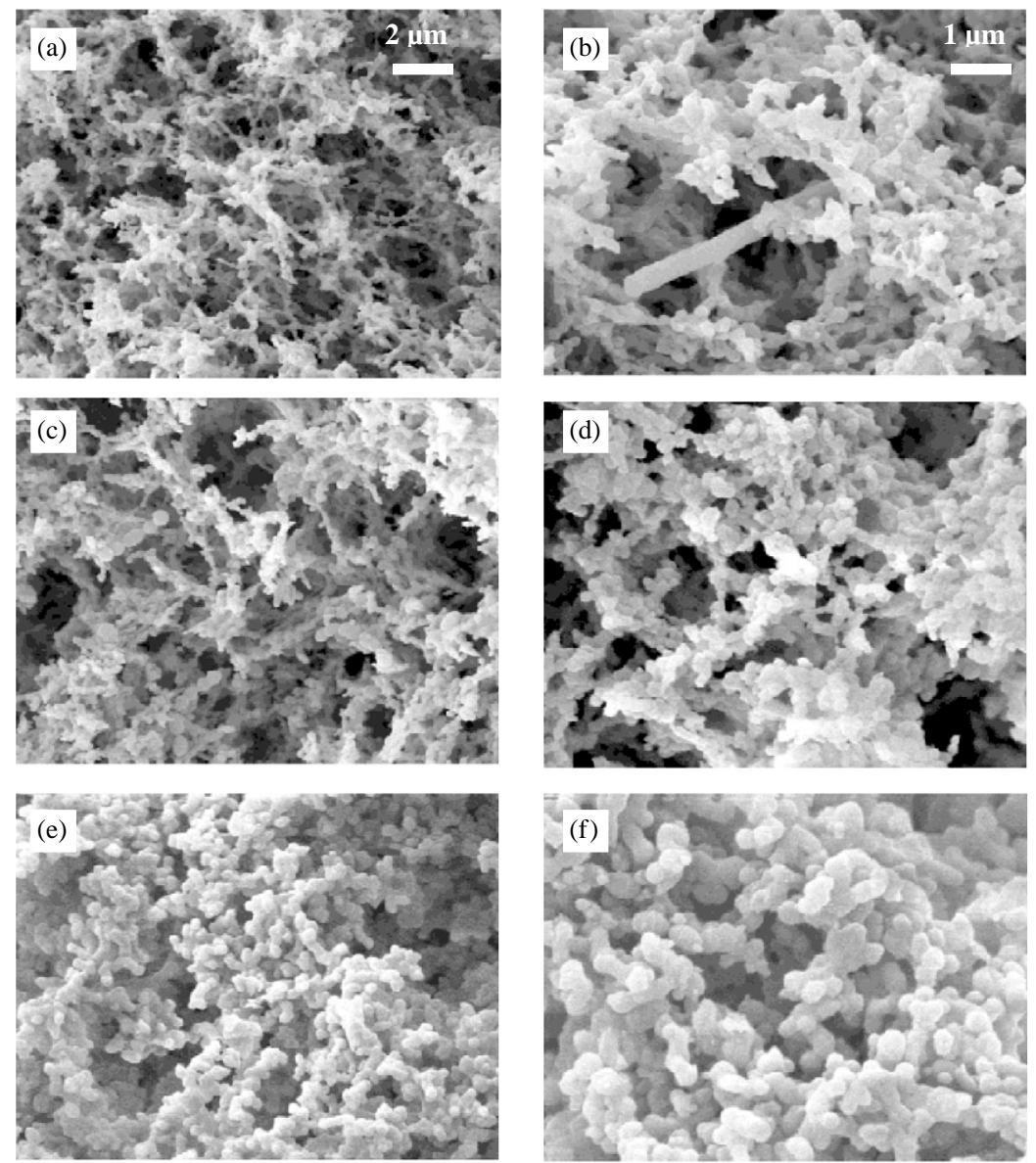

Fig. 4. Scanning electron micrographs of acid gels prepared from milk protein systems: micellar casein (systR: e and f), micellar casein plus $\beta$ lactoglobulin (systB: $\mathrm{c}$ and d), and micellar casein plus ovalbumin (systO: a and b). The protein systems were heat-treated $\left(90^{\circ} \mathrm{C}\right.$ for $\left.24 \mathrm{~min}\right)$ prior to slow quiescent acidification at $\mathrm{pH} 4.6$, which was achieved by the addition of a starter culture to the systems at $42^{\circ} \mathrm{C}$. See text for details of protein systems and heat treatment.

interaction between ovalbumin and $\kappa$-casein was not a major event, as we did not observe any modification of the composition of the soluble casein. The question which thus arises is why $\beta \mathrm{LG}$ provoked solubilisation of $\kappa$-casein and why ovalbumin did not, despite the fact that ovalbumin has the same ability to interact with casein as $\beta \mathrm{LG}$ ?

On the other hand, $\beta \mathrm{LG}$ was completely recovered in the two acid-precipitable fractions, while this was not the case with ovalbumin. No residual native ovalbumin was found in the heat-treated suspensions by ion exchange HPLC. A denatured and, probably, insoluble fraction of ovalbumin was not present in the acidprecipitable fractions. On the other hand, it is possible that an ovalbumin fraction did not enter the acrylamide gel, because it consists of fairly large polymers and because there was an insufficient concentration of 2mercaptoethanol. In fact, very large polymers were found with ovalbumin, as demonstated by particle size and viscosity measurements, and the dilution buffer of proteins in SDS-PAGE analysis did not contain urea.
Polymers of ovalbumin or of casein with ovalbumin probably appeared during the heat treatment as a result of disulphide, hydrophobic and hydrogen interactions. As globular proteins were absent on SDS-PAGE without reduction, complexes containing globular proteins involved $\mathrm{SS} / \mathrm{SH}$ interchanges for $\beta \mathrm{LG}$ as for ovalbumin.

The solubility of $\kappa$ - and $\alpha_{\mathrm{s} 1}$-casein increased and decreased, respectively, by heating the casein in the presence of $\beta$ LG. No change was observed without $\beta$ LG. The high level of soluble $\kappa$-casein in the heated suspension of systB compared to that reported in previous studies (Smits et al., 1980; Law, 1996; Singh et al., 1996) can be attributed to: (i) the higher concentration of milk in the current study; a higher casein concentration in milk leads to a greater solubilisation (Anema et al., 2000); (ii) the absence of $\alpha$ lactalbumin in the current protein systems; and (iii) the use in the current study of a milk model with native phosphocaseinate that can behave slightly differently from milk. A small release of colloidal calcium phosphate $(\mathrm{CCP})$ can arise during the manufacture of 
phosphocaseinate. Depletion of CCP leads to enhanced casein dissociation by heat treatment (Anema et al., 2000).

\subsection{Similarities in the behaviour of ovalbumin and $\beta$ - lactoglobulin}

The microstructures of gels obtained from systR appeared as a coarse network of large particles. They resembled gels obtained from unheated milk (Harwalkar \& Kalab, 1980; Parnell-Clunies, Kakuda, \& Smith, 1987). In contrast, gels with $\beta \mathrm{LG}$ or ovalbumin consisted of a more branched network of smaller particles and were less heterogeneous (Kalab, Emmons, \& Sargant, 1976; Davies, Shankar, Brooker, \& Hobbs, 1978; Creamer, Berry, \& Matheson, 1978; Harwalkar et al., 1980; Parnell-Clunies et al., 1987; Lucey, Teo, Munro, \& Singh, 1998d). The gels from heated systB and heated systO can probably retain more whey (as gels from heated milk) than the coarser acid gels from unheated milk or from heated systR (Tamime \& Robinson, 1999). According to Kalab et al. (1976), the mean particle sizes of particles in acid gels from unheated and heated milks are 230 and $460 \mathrm{~nm}$, respectively; this difference in particle size between acid gels from heated and unheated milks is similar whether GDL or starter bacteria are used as the acidifying agent (Harwalkar et al., 1980).

The acid-induced changes in rheological characteristics during acid gelation of the protein systems could be correlated with the loss of solubility of globular proteins. Polymers formed during heating of systB and systO had the same effect on casein during acid gelation. The same microstructure was observed in the acid gels for systB and systO. BLG or ovalbumin in heated systB could act through the negative charges they add to casein (this is believed to hinder acid gelation). It is noteworthy that $\beta \mathrm{LG}$ is no longer negatively charged at pH 5 ( $\mathrm{pH}$ at gelation), while casein and ovalbumin are negatively charged. In this respect, $\beta \mathrm{LG}$ and ovalbumin had close $\mathrm{pH}_{\mathrm{i}}$ values but they lost their solubility at different $\mathrm{pH}$ values. BLG and ovalbumin could also act through the hydrophobicity they add to casein which enhances the destabilisation of the suspension. Ovalbumin is more hydrophobic than $\beta \mathrm{LG}$, as evidenced by its higher retention in $\mathrm{C} 4$ reverse phase chromatography (Nau, Mallard, Pages, \& Brulé, 1999). If in our conditions ovalbumin formed a complex with the casein particle, thereby adding more hydrophobicity to it than $\beta \mathrm{LG}$, a higher electrostatic repulsion would be necessary to protect this particle against aggregation. Acid gelation of the heated systO began at a higher $\mathrm{pH}$ value than in the heated systB.

The theoretical (based on amino acid composition) and experimental values of $\mathrm{pH}_{\mathrm{i}}$ for $\beta \mathrm{LG}$ and ovalbumin are different $\left(\beta \mathrm{LG}\right.$ : theoretical $\mathrm{pH}_{\mathrm{i}}=4.64$, experimental
$\mathrm{pH}_{\mathrm{i}}=5.1$; ovalbumin: theoretical $\mathrm{pH}_{\mathrm{i}}=5.02$, experimental =4.75). This suggests that the $\mathrm{pH}_{\mathrm{i}}$ of the native protein is scarcely affected by its charge when the protein became denatured. This can be explained firstly because heat treatment exposes the charged masked residues and secondly because the $\mathrm{pH}_{\mathrm{i}}$ of protein is affected by ionic strength (and by ionic calcium). Heat treatment modifies the calcium phosphate precipitation and therefore ionic calcium.

We contend that casein particles can be covered with globular proteins and that this layer can define its physicochemical properties. It is possible that the early decrease in $\tan \delta$ can be attributed to aggregation of soluble complexes containing $\kappa$-casein and $\beta \mathrm{LG}$ through hydrophobic interactions. Micellar casein would aggregate later, by casein-casein aggregation. Fractionation and addition of these complexes to unheated milk would confirm this hypothesis.

The effect of $\beta \mathrm{LG}$ and ovalbumin on acid gelation of casein in a milk ultrafiltrate is indirectly a cold-gelation phenomenon instigated by a drop in $\mathrm{pH}$ at $42^{\circ} \mathrm{C}$. However the reactivity of these two globular proteins is determined by heating conditions: heating time and temperature, $\mathrm{pH}$ and ionic strength.

\section{Conclusions}

The protein systems used in this study behaved in a similar way to milk during acid gelation: syst $\mathrm{R}$ behaved as unheated milk, while systB as heated milk. This confirms our knowledge of the role of whey proteins during the acid gelation of heated milk.

Moreover, systO led to a higher storage modulus than systB, suggesting that substitution of whey proteins for ovalbumin can lead to new texture properties of acid gels.

\section{Acknowledgements}

The authors thank J. Fauquant for providing $\beta$ lactoglobulin, F. Michel for micelle size and $\zeta$ potential measurements, $G$. Henry for titration of suspensions with ANS, G. Jan for suggestions on revising the manuscript and T. Croguennec for valuable discussion.

\section{References}

Anema, S. G. (1998). Effect of milk concentration on heat-induced, $\mathrm{pH}$-dependent dissociation of casein from micelles in reconstituted skim milk at temperatures between 20 and $120^{\circ} \mathrm{C}$. Journal of Agricultural and Food Chemistry, 46(6), 2299-2305.

Anema, S. G., \& Klostermeyer, H. (1997). Heat-induced, pHdependent dissociation of casein micelles on heating reconstituted 
skim milk at temperatures below $100^{\circ}$ C. Journal of Agricultural and Food Chemistry, 45(4), 1108-1115.

Anema, S. G., \& Li, Y. (2000). Further studies on the heat-induced, $\mathrm{pH}$ dependent dissociation of casein from the micelles in reconstituted skim milk. Lebensmitel- Wissenschaft und-Technologie, 33(5), 335-343.

Beveridge, T., Jones, L., \& Tung, M. A. (1984). Progel and gel formation and reversibility of gelation of whey, soybean and albumen protein gels. Journal of Agricultural and Food Chemistry, 32(2), 307-313.

Corredig, M., \& Dalgleish, D. G. (1999). The mechanisms of the heatinduced interaction of whey proteins with casein micelles in milk. International Dairy Journal, 9(3/6), 233-236.

Creamer, L. K., Berry, G. P., \& Matheson, A. R. (1978). The effect of $\mathrm{pH}$ on protein aggregation in heated skim milk. New Zealand Journal of Dairy Science and Technology, 13(1), 9-15.

Croguennec, T., Nau, F., Pezennec, S., \& Brulé, G. (2000). Simple rapid procedure for preparation of large quantities of ovalbumin. Journal of Agricultural and Food Chemistry, 48(10), 4883-4889.

Dalgleish, D. G. (1984). Measurement of electrophoretic mobilities and zeta-potentials of particles from milk using laser Doppler electrophoresis. Journal of Dairy Research, 51(3), 425-438.

Dalgleish, D. G. (1990). Denaturation and aggregation of serum proteins and caseins in heated milk. Journal of Agricultural and Food Chemistry, 38(11), 1995-1999.

Dalgleish, D. G., van Mourik, L., \& Corredig, M. (1997). Heatinduced interactions of whey proteins and casein micelles with different concentrations of $\alpha$-Lactalbumin and $\beta$-Lactoglobulin. Journal of Agricultural and Food Chemistry, 45(12), 4806-4813.

Dannenberg, F., \& Kessler, H. G. (1988). Effect of denaturation of $\beta$ lactoglobulin on texture properties of set-style nonfat yogurt. 1 . Syneresis. Milchwissenschaft, 43(11), 632-635.

Davies, F. L., Shankar, P. A., Brooker, B. E., \& Hobbs, D. G. (1978). A heat-induced change in the ultrastructure of milk and its effect on gel formation in yoghurt. Journal of Dairy Research, 45(1), 53-58.

Doi, E., \& Kitabatake, N. (1997). Structure and functionality of egg proteins. In S. Damodaran, \& A. Paraf (Eds.), Food proteins and their applications (pp. 325-340). New York: Marcel Dekker, Inc.

Halbert, C., O'Kennedy, B. T., Hallihan, A., \& Kelly, P. M. (2000). Stabilisation of calcium phosphate using denatured whey proteins. Milchwissenschaft, 55(7), 386-389.

Harwalkar, V. R., \& Kalab, M. (1980). Milk gel structure. XI. Electron microscopy of glucono-delta-lactone-induced skim milk gels. Journal of Texture Studies, 11(1), 35-49.

Harwalkar, V. R., \& Kalab, M. (1983). Susceptibility of yoghurt to syneresis. Comparison of centrifugation and drainage methods. Milchwissenschaft, 38(9), 517-522.

Harwalkar, V. R., \& Kalab, M. (1986). Relationship between microstructure and susceptibility to syneresis in yoghurt made from reconstituted nonfat dry milk. Food Microstructure, 5(2), 287-294.

Hatta, H., Kitabatake, N., \& Doi, E. (1986). Turbidity and hardness of a heat-induced gel of hen egg ovalbumin. Agricultural and Biological Chemistry, 50(8), 2083-2089.

Hayakawa, S., \& Nakai, S. (1985). Contribution of hydrophobicity, net charge and sulfhydryl groups to thermal properties of ovalbumin. Canadian Institute of Food Science and Technological Journal, 18(4), 290-295.

Hoffmann, M. (1997). $\beta$-lactoglobulin: denaturation and aggregation. Ph.D. Thesis, NIZO.

Kalab, M., Emmons, D. B., \& Sargant, A. G. (1976). Milk gel structure. V. Microstructure of yoghurt as related to the heating of milk. Milchwissenschaft, 31(7), 402-408.
Kitabatake, N., Ishida, A., \& Doi, E. (1988). Physicochemical and functional properties of hen ovalbumin dephosphorylated by acid phosphatase. Agricultural and Biological Chemistry, 52(4), 967-973.

Laligant, A., Famelart, M. H., Paquet, D., \& Brulé, G. (2003). Fermentation by lactic bacteria at two temperatures of pre-heated reconstituted milk-II Dynamic approach of the gel construction. Le lait, in press.

Law, A. J. R. (1996). Effects of heat treatment and acidification on the dissociation of bovine casein micelles. Journal of Dairy Research, 63(1), 35-48.

Lin, J. C. C., \& Cunningham, F. E. (1984). Preparation of a yoghurtlike product containing egg white. Journal of Food Science, 49(6), 1444-1452.

Lucey, J. A., Munro, P. A., \& Singh, H. (1998a). Whey separation in acid skim milk gels made with glucono-delta-lactone: Effects of heat treatment and gelation temperature. Journal of Texture Studies, 29(4), 413-426.

Lucey, J. A., \& Singh, H. (1998). Formation and physical properties of acid milk gels: A review. Food Research International, 30(7), $529-542$

Lucey, J. A., Tamehana, M., Singh, H., \& Munro, P. A. (1998b). Effect of interactions between denatured whey proteins and casein micelles on the formation and rheological properties of acid skim milk gels. Journal of Dairy Research, 65(4), 555-567.

Lucey, J. A., Tamehana, M., Singh, H., \& Munro, P. A. (1998c). A comparison of the formation, rheological properties and microstructure of acid skim milk gels made with a bacterial culture or glucono-delta-lactone. Food Research International, 31(2), $147-155$

Lucey, J. A., Teo, C. T., Munro, P. A., \& Singh, H. (1998d). Microstructure, permeability and appearance of acid gels made from heated skim milk. Food Hydrocolloids, 12(2), 159-165.

Mackenzie, K. A. (1982). Cultured egg-milk product, Patent number GB2116819A, p. 2.

Margoshes, B. A. (1990). Correlation of protein sulfhydryls with strength of heat-formed egg white gels. Journal of Food Science, 55(6), 1753-1756.

Marshall, R. J., \& Green, M. L. (1980). The effect of the chemical structure of additives on the coagulation of casein micelle suspensions by rennet. Journal of Dairy Research, 47(3), 359-369.

Michalski, M.C., Michel, F., \& Briard, V. (2002). On the size distribution and $\zeta$-potential of homogenized milk fat globules. In: M. Anton. Recent research developments in food emulsions. Kercila: Research Signpost, India, 49-65.

Mine, Y. (1992). Sulfhydryl groups changes in heat-induced soluble egg white aggregates in relation to molecular size. Journal of Food Science, 57(1), 254-255.

Muller, G., Volley, W., \& Zumstein, E. (1987). Patent number EP0097128A2, p. 12 .

Nau, F., Mallard, A., Pages, J., \& Brulé, G. (1999). Reversed-phase liquid chromatography of egg white proteins. Optimization of ovalbumin elution. Journal of Liquid Chromatography and Related Technology, 22(8), 1129-1147.

Parnell-Clunies, E., Kakuda, Y., \& Smith, A. K. (1987). Microstructure of yogurt as affected by heat treatment of milk. Milchwissenschaft, 42(7), 413-417.

Pezennec, S., Gauthier, F., Alonso, C., Graner, F., Croguennec, T., \& Renault, A. (2000). The protein net electric charge determines the surface rheological properties of ovalbumin adsorbed at the airwater interface. Food Hydrocolloids, 14(5), 463-472.

Sato, Y., Iwatsuki, K., \& Hayakawa, M. (1976). Interaction between ovalbumin and kappa or beta casein due to heating. Agricultural and Biological Chemistry, 41(8), 1331-1338. 
Singh, H., \& Fox, P. F. (1985). Heat stability of milk: pH-dependent dissociation of micellar $\kappa$-casein on heating milk at ultra high temperatures. Journal of Dairy Research, 52(4), 529-538.

Singh, H., \& Fox, P. F. (1987). Heat stability of milk: Role of $\beta$ lactoglobulin in the $\mathrm{pH}$-dependent dissociation of micellar $\kappa$ casein. Journal of Dairy Research, 54(4), 509-521.

Singh, H., Robert, M. S., Munro, P. A., \& Cheng Tet Teo. (1996). Acid-induced dissociation of casein micelles in milk: Effects of heat treatment. Journal of Dairy Science, 79, 1340-1346.

Smits, P., \& van Brouwershaven, J. H. (1980). Heat-induced association of $\beta$-lactoglobulin and casein micelles. Journal of Dairy Research, 47(3), 313-325.

Sun Yuanxia, \& Hayakawa, S. (2001). Thermally induced aggregates in mixtures of $\alpha$-lactalbumin with ovalbumins from different avian species. Journal of Agricultural and Food Chemistry, 49(5), 2511-2517.
Tae, K. Y. (1995). The effects of dried egg white addition on acid production by lactic bacteria and quality of curd yoghurt. Korean Journal of Food Science and Technology, 27(4), 458-463.

Tae, K. Y., \& Min, K. H. (1995). Changes in acid production, sensory properties and volatile flavour compounds of yoghurt during lactic culturing of milk with added dried egg white. Korean Journal of Food Science and Technology, 27(4), 612-617.

Tamime, A. Y., \& Robinson, R. K. (1999). Yoghurt science and technology. Cambridge: Woodhead Publishing Limited.

Verheul, M. (1998). Aggregation and gelation of whey proteins. Ph.D. Thesis, University Twente, Enschede.

Visser, S. A. (1962). Occurrence of calcium phosphates in the presence of organic substances, especially proteins. Journal of Dairy Science, 45(6), 710-716. 